\title{
Potensi tepung daun sirsak, serai, kenikir, jeruk nipis, dan kluwih terhadap kumbang bubuk kedelai (Callosobruchus analis F.) pada kedelai (Glyxine max L.) dalam simpanan
}

\author{
The potency of flour leaves of soursop, lemon grass, kenikir, lime, and kluwih \\ towards soybean powder's beetles (Callosobruchus analis F.) on soybean (Glyxine \\ max L.) in the storage
}

\author{
Laily Dwi Dzulhijja1, Wagiyana, , , Sigit Prastowo² \\ ${ }^{1}$ Program Studi Agroteknologi, Fakultas Pertanian, Universitas Jember, Jember Indonesia \\ ${ }^{2}$ Program Studi Proteksi Tanaman, Fakultas Pertanian, Universitas Jember, Jember, Indonesia
}

\section{INFORMASI ARTIKEL}

\author{
*Korespondensi: \\ Wagiyana \\ wagiyana.faperta@unej.ac.id
}

Informasi proses: Received: 1 Juni 2020 Accepted: 8 Juni 2020 Published: 14 Juli 2020

Cara sitasi: Dzulhijja LD, Wagiyana, Prastowo S. 2020. Potensi tepung daun sirsak, serai, kenikir, jeruk nipis, dan kluwih terhadap kumbang bubuk kedelai (Callosobruchus analis F.) pada kedelai (Glyxine max L.) dalam simpanan. Jurnal Proteksi Tanaman Tropis 1(2): $55-61$

DOI:

\begin{abstract}
This study aims to determine the effect of soursop leaf flour, lemongrass flour, kenikir leaf flour, lime leaf flour, and kluwih leaf flour on 1) mortality, 2) damage to seeds, 3) shrinkage of seed weight, 4) appearance of adult $C$. analis on soybean seeds in deposits and 5) laying eggs of $C$. analis imago female eggs, 6) probit analysis $\mathrm{LT}_{50}$. The experiment was carried out using a Completely Randomized Design (CRD). As treatments are: A) controls; B) soursop leaf flour in doses of $1 \mathrm{~g}, 2 \mathrm{~g}$, and $3 \mathrm{~g}$; C) Serai leaf flour with doses of $1 \mathrm{~g}, 2 \mathrm{~g}$, and $3 \mathrm{~g}$; D) kenikir leaf flour with doses of $1 \mathrm{~g}, 2 \mathrm{~g}$, and $3 \mathrm{~g}$; E) lime leaf flour with doses of $1 \mathrm{~g}, 2 \mathrm{~g}$, and $3 \mathrm{~g}$; and F) kluwih leaf flour with doses of $1 \mathrm{~g}, 2 \mathrm{~g}$, and $3 \mathrm{~g}$. Each treatment uses five replications. The observed parameters were analyzed by "F" test variance then if it was significantly different to find out the difference in the effect of treatment, a Tukey HSD test was conducted at a level of 5\% distrust. The best mortality results using the treatment of soursop leaf flour dose $3 \mathrm{~g}$ on five days amounted to 1.80 tails; 1 month is $6.60 ; 2$ months totaling 13.40; and three months totaling 11.20. The results of the observation of the number of eggs produced by $C$. analis the best analyst was the treatment of soursop leaf flour dose $3 \mathrm{~g}$ on five days amounting to 139 items, one month 119.20 items; 2 months 91.20 items; and three months 72.20 items. The best imago observation results were the treatment of soursop leaf flour dose $3 \mathrm{~g}$ at one month amounting to 132.20 tails, while at two months, there were 79 heads. The best observation of seed damage and shrinkage of seed weight was the treatment of soursop leaf flour with a dose of $3 \mathrm{~g}$, in the damage of seeds of 67.40 grains of seed damage; while the seed weight is reduced by $17.94 \mathrm{~g}$. The results of the best analysis of Probit $\mathrm{LT}_{50}$ were treatment of soursop leaf flour with a dose of $3 \mathrm{~g}$ because it could kill $50 \%$ of the population $C$. analis with a relatively short time were 9 days after treatment.
\end{abstract}

Keywords: C. analis, leaf flour, dosage 


\section{Pendahuluan}

Kedelai merupakan komoditas yang penting di Indonesia, karena kandungan kedelai berupa protein, protein dalam kedelai sangat tinggi dan biasanya digunakan pada bahan industri maupun pakan ternak. Di Indonesia sendiri banyak sekali permintaan akan pasokan kedelai karena sudah menjadi bahan paten untuk dijadikan bahan baku suatu olahan industri. Menurut BPS (2017) diperkirakan dari tahun 2016 kenaikan mencapai 183.176 yaitu sekitar $30 \%$ dan kenaikan akan permintaan kedelai terus meningkat.

Hama yang berpotensi berada pada kedelai dalam simpanan yaitu Callosobruchus analis. Harinta (2013), menyatakan bahwa kerusakan akan serangan hama gudang ini diperkirakan dapat mencapai kerugian yang fatal dan kedelai pastinya tidak dapat diproduksi menjadi bahan baku karena rusak menjadi bubuk. Kerusakan dan penyusutan bobot biji kedelai yang disebabkan oleh Kumbang bubuk kedelai (C. analis) mencapai 89,71 persen, sedangkan berat serangan kumbang ini pada biji kacang-kacangan dapat menyebabkan penyusutan bobot biji yang disimpan mencapai 70 persen.

Menurut Harinta (2013), bahwa untuk menekan kerugian pada biji kacang-kacangan yang disimpan akibat serangan kumbang $C$. analis maka diperlukan usaha pengendalian. Dengan penggunaan bahan non toksik (seperti abu kayu dan abu sekam) dan pestisida nabati (seperti tepung daun sirsak, tepung daun serai, tepung daun kluwih, tepung daun jeruk nipis, dan tepung daun kenikir) untuk pengendalian hama gudang.

Teknik pengendalian yang banyak dilakukan yaitu dengan menggunakan insektisida sintetis, yang daya bunuhnya luas. Namun cara tersebut kurang baik karena dapat membahayakan manusia, sehingga perlu dilakukan pengendalian secara alami dengan menggunkan bahan nabati. Daun sirsak (Annona muricata L.), daun serai (Cymbopogon nardus), daun kenikir (Cosmos caudatus Kunth.), daun jeruk nipis (Citrus aurantiifolia), dan daun kluwih (Artocarpus communis F.). merupakan tanaman yang memiliki potensi sebagai insektisida nabati untuk pengendalian hama C. analis.

\section{Metode penelitian}

\section{Waktu dan Tempat}

Penelitian dengan judul "Potensi Daun Sirsak (Annona muricata), Daun Serai (Cymbopogon nardus), Daun Kenikir (Cosmos caudatus), Daun Jeruk Nipis (Cytrus aurantiifolia), dan Daun Kluwih (Artocarpus communis) Terhadap Hama Kumbang Bubuk Kedelai (Callosobruchus analis) pada Kedelai (Glyxine max) dalam Simpanan" di lakukan di Laboratorium Hama dan Penyakit Tanaman, Fakultas Pertanian, Universitas Jember mulai bulan Desember 2016 sampai bulan Maret 2017.

\section{Pelaksanaan Riset}

Penelitian ini dilaksanakan untuk mengetahui potensi tepung daun sirsak, tepung daun serai, tepung daun kenikir, tepung daun jeruk nipis, dan tepung daun kluwih terhadap mortalitas kumbang $C$. analis dan mengetahui dosis tepung daun yang dapat berpengaruh terhadap mortalitas $C$. analis.

Penelitian disusun dengan metode Rancangan Acak Lengkap (RAL), terdiri dari 16 perlakuan dan tiap perlakuan diulang lima kali (Tabel 1). Dari setiap perlakuan, dilakukan pengulangan sebanyak lima kali sehingga diperoleh 80 stoples.

Telur serangga $C$. analis diperoleh dari kedelai pasca panen dalam gudang simpanan, yang mana sebelumnya telah dikoleksi sedemikian rupa sehingga diperoleh banyak imago. Kriteria daun yang digunakan pada penelitian ini yaitu memiliki kemasakan optimal, yaitu daun yang tidak terlalu tua dan tidak terlalu muda. Tepung daun yang telah dipilih kemudian dikeringkan. Selanjutnya daun yang telah dikeringkan, dihaluskan, dijadikan tepung, dan ditimbang.

Tabel 1. Perlakuan tepung daun dan kontrol

\begin{tabular}{ll}
\hline Pelakuan & Deskripsi \\
\hline A & Kontrol \\
B1 & Kedelai di simpan dengan tepung Daun sirsak $1 \mathrm{~g} / 500 \mathrm{~g}$ biji \\
B2 & Kedelai di simpan dengan tepung Daun sirsak $2 \mathrm{~g} / 500 \mathrm{~g}$ biji \\
B3 & Kedelai di simpan dengan tepung Daun sirsak $3 \mathrm{~g} / 500 \mathrm{~g}$ biji \\
C1 & Kedelai di simpan dengan tepung Daun serai $1 \mathrm{~g} / 500 \mathrm{~g}$ biji \\
C2 & Kedelai di simpan dengan tepung Daun serai $2 \mathrm{~g} / 500 \mathrm{~g}$ biji \\
$\mathrm{C} 3$ & Kedelai di simpan dengan tepung Daun serai $3 \mathrm{~g} / 500 \mathrm{~g}$ biji \\
D1 & Kedelai di simpan dengan tepung Daun kenikir $1 \mathrm{~g} / 500 \mathrm{~g}$ biji \\
D2 & Kedelai di simpan dengan tepung Daun kenikir $2 \mathrm{~g} / 500 \mathrm{~g}$ biji \\
D3 & Kedelai di simpan dengan tepung Daun kenikir $3 \mathrm{~g} / 500 \mathrm{~g}$ biji \\
E1 & Kedelai di simpan dengan tepung Daun jeruk nipis $1 \mathrm{~g} / 500 \mathrm{~g}$ biji \\
E2 & Kedelai di simpan dengan tepung Daun jeruk nipis $3 \mathrm{~g} / 500 \mathrm{~g}$ biji \\
E3 & Kedelai di simpan dengan tepung Daun kluwih $1 \mathrm{~g} / 500 \mathrm{~g}$ biji \\
F1 & Kedelai di simpan dengan tepung Daun kluwih $2 \mathrm{~g} / 500 \mathrm{~g}$ biji \\
F2 & Kedelai di simpan dengan tepung Daun kluwih $3 \mathrm{~g} / 500 \mathrm{~g}$ biji \\
F3 &
\end{tabular}


Timbang 500 g biji kedelai dan diletakan pada stoples yaitu sebanyak 80 stoples. Tepung daun dimasukkan kedalam stoples sesuai dosis yg telah ditentukan. Sepuluh pasang imago $C$. analis diletakkan dalam stoples dibandingkan dengan kontrol, diulang lima kali. Stoples ditutup rapat agar terhindar dari singgungan hewan lain.

Penyimpanan kedelai dalam stoples dilakukan dengan lama 3 bulan, dan selama penyimpanan dilakukan pengamatan setiap 5 hari dan 1 bulan sekali dengan jumlah pengamatan 4 kali yaitu pada 5 hari, 1 bulan, 2 bulan, dan 3 bulan. Mengamati mortalitas serangga uji, jumlah telur yang dihasilkan, munculnya imago baru F1 dan F2, kerusakan biji dan susut bobot biji, dan daya toksisitas $\mathrm{LT}_{50}$ tepung daun dengan anailis probit selama 1 bulan.

\section{Variabel Pengamatan}

Pengamatan mortalitas C. analis dilakukan 4 kali pengamatan selama 3 bulan, yaitu pada 5 hari, 1 bulan, 2 bulan, dan 3 bulan. Pengamatan jumlah telur $C$. analis dilakukan untuk mengetahui adanya pengaruh perlakuan tepung daun. Dihitung banyaknya telur yang dihasilkan pada pertama masa kawin imago pejantan dan betina yaitu pada hari ke5 setelah perlakuan, dan bulan berikutnya hingga 3 bulan. Jumlah telur menetas dapat diketahui dengan mengetahui jumlah telur yang diletakkan imago terlebih dahulu. Jumlah telur yang menetas dapat dihitung apabila telur telah menetas menjadi imago F1 dan F2. Penghitungan kemunculan imago $C$. analis dilakukan pada bulan ke 1 dan bulan ke 2 .

Pengamatan kerusakan biji dilakukan dengan cara menghitung jumlah biji rusak dan menghitung pula jumlah biji sehat, namun mula-mula harus mengetahui jumlah total biji yang terdapat pada $500 \mathrm{~g}$ biji dalam stoples. Pengamatan kerusakan biji dilakukan pada bulan ke 3 yaitu pengamatan terakhir selama penelitian.

Pengamatan susut bobot biji kedelai dilakukan dengan cara mengetahui persentasi susut bobot yang semula, hingga berjalan 3 bulan dan mengetahui bagaimana perubahan bobot yang diakibatkan oleh serangga hama $C$. analis.

Untuk menilai toksisitas insektisida dapat menggunakan metode pengujian analisis probit yang merupakan ukuran untuk mengukur daya racun jenis pestisida. Pada uji efektifitas ditunjukan Lethal Time $\left(\mathrm{LT}_{50}\right)$ yang berarti berapa waktu yang diperlukan untuk menyebabkan kematian $50 \%$ dari serangga percobaan.

Data yang diperoleh dianalisis dengan sidik ragam uji "F" kemudian apabila berbeda nyata untuk mengetahui perbedaan pengaruh perlakuan dilakukan Uji Beda Nyata Jujur (BNJ) pada taraf ketidak percayaan $5 \%$.

\section{Hasil dan Pembahasan}

\section{Mortalitas Imago C. analis}

Berdasarkan penelitian yang telah dilakukan menunjukkan bahwa efektifitas insektisida nabati berbentuk serbuk memberikan hasil yang berbeda sangat nyata terhadap

mortalitas $C$. analis pada setiap perlakuan. Selanjutnya hasil analisis Uji Beda Nyata Jujur pada taraf ketidak percayaan 5\%, menunjukkan bahwa mortalitas imago $C$. analis pada perlakuan dosis berbeda nyata dengan kontrol (Tabel 2).

Mortalitas C. analis pada hari 5 menunjukan hasil yang berbeda dari setiap perlakuan, dimana perlakuan tepung daun sirsak dosis $3 \mathrm{~g}$ (B3) merupakan perlakuan yang terbaik pada $5 \mathrm{hsp}$. Pada perlakuan tepung daun kluwih dari dosis $1 \mathrm{~g}$ hingga dosis $3 \mathrm{~g}$ menunjukan belum terdapat interaksi mortalitas yang ada, hal ini karena pengaruh tepung daun kluwih berpengaruh namun lamban. Pada hasil 1 bulan pada perlakuan tepung daun sirsak yang paling berpengaruh dibandingkan perlakuan lain, yakni dengan mortalitas 2,83 ekor serangga mati merupakan perlakuan terbaik. Pada hasil 2 bulan perlakuan terbaik yaitu tepung daun sirsak dosis 3g (B3) dengan nilai 3,76 ekor serangga mati. Pada hasil pengamatan bulan 3 , perlakuan tepung daun sirsak dosis $3 \mathrm{~g}$ (B3) memberikan hasil mortalitas yang terbaik, mortalitas tepung daun sirsak berbeda sangat nyata dibandingkan perlakuan lain. Mortalitas pada perlakuan dosis tepung diduga mempunyai

Tabel 2. Pengaruh tepung daun terhadap mortalitas hama $C$. analis pada 5 hari,1 bulan, 2 bulan, dan 3 bulan setelah perlakuan.

\begin{tabular}{lllll}
\hline \multirow{2}{*}{ Pelakuan } & \multicolumn{5}{c}{ Mortalitas pada } \\
\cline { 2 - 5 } & 5 hari & 1 bulan & 2 bulan & 3 bulan \\
\hline $\mathrm{A}$ & $1,00 \mathrm{~b}$ & $1,46 \mathrm{~d}$ & $1,76 \mathrm{~b}$ & $1,90 \mathrm{c}$ \\
$\mathrm{B}_{1}$ & $1,28 \mathrm{ab}$ & $2,43 \mathrm{abc}$ & $3,14 \mathrm{a}$ & $2,81 \mathrm{ab}$ \\
$\mathrm{B}_{2}$ & $1,59 \mathrm{ab}$ & $2,83 \mathrm{a}$ & $3,72 \mathrm{a}$ & $3,57 \mathrm{a}$ \\
$\mathrm{B}_{3}$ & $1,63 \mathrm{a}$ & $2,68 \mathrm{ab}$ & $3,76 \mathrm{a}$ & $3,49 \mathrm{a}$ \\
$\mathrm{C}_{1}$ & $1,00 \mathrm{~b}$ & $1,56 \mathrm{~cd}$ & $1,71 \mathrm{~b}$ & $1,94 \mathrm{c}$ \\
$\mathrm{C}_{2}$ & $1,25 \mathrm{ab}$ & $1,66 \mathrm{~cd}$ & $1,94 \mathrm{~b}$ & $1,92 \mathrm{c}$ \\
$\mathrm{C}_{3}$ & $1,33 \mathrm{ab}$ & $2,04 \mathrm{abcd}$ & $2,07 \mathrm{~b}$ & $2,26 \mathrm{bc}$ \\
$\mathrm{D}_{1}$ & $1,00 \mathrm{~b}$ & $1,35 \mathrm{~d}$ & $1,85 \mathrm{~b}$ & $1,66 \mathrm{c}$ \\
$\mathrm{D}_{2}$ & $1,37 \mathrm{ab}$ & $1,64 \mathrm{~cd}$ & $1,82 \mathrm{~b}$ & $1,82 \mathrm{c}$ \\
$\mathrm{D}_{3}$ & $1,37 \mathrm{ab}$ & $1,92 \mathrm{abcd}$ & $2,08 \mathrm{~b}$ & $1,82 \mathrm{c}$ \\
$\mathrm{E}_{1}$ & $1,00 \mathrm{~b}$ & $1,76 \mathrm{bcd}$ & $1,70 \mathrm{~b}$ & $1,82 \mathrm{c}$ \\
$\mathrm{E}_{2}$ & $1,23 \mathrm{ab}$ & $1,63 \mathrm{~cd}$ & $1,87 \mathrm{~b}$ & $1,92 \mathrm{c}$ \\
$\mathrm{E}_{3}$ & $1,31 \mathrm{ab}$ & $1,81 \mathrm{bcd}$ & $2,15 \mathrm{~b}$ & $2,05 \mathrm{bc}$ \\
$\mathrm{F}_{1}$ & $1,00 \mathrm{~b}$ & $1,38 \mathrm{~d}$ & $1,53 \mathrm{~b}$ & $1,61 \mathrm{c}$ \\
$\mathrm{F}_{2}$ & $1,00 \mathrm{~b}$ & $1,76 \mathrm{bcd}$ & $1,64 \mathrm{~b}$ & $1,52 \mathrm{c}$ \\
$\mathrm{F}_{3}$ & $1,00 \mathrm{~b}$ & $1,72 \mathrm{~cd}$ & $1,87 \mathrm{~b}$ & $1,76 \mathrm{c}$ \\
\hline
\end{tabular}

Keterangan: Angka-angka yang diikuti huruf yang sama pada kolom yang sama tidak berbeda nyata pada taraf $5 \%$ berdasar uji BNJ (data ditransformasi dengan akar kuadrat +1 sebelum dianalisis). 
kandungan senyawa tertentu. Seperti misalnya daun sirsak yang mempunyai senyawa aktif yaitu annonasinon dan annonasin, yang bisa digunakan sebagai bahan insektisida nabati (Suranto 2011).

Imago C. analis yang diletakkan ke dalam campuran biji kedelai dengan tepung daun, akan masuk disela sela campuran tersebut. Selanjutnya imago C. analis akan secara langsung bersentuhan dengan tepung daun tersebut. Kontak ini di duga menyebabkan rasa pedih. Seperti pernyataan Kardiman (2005), bahwa daun sirsak mempunyai senyawa asetogenin, bagi serangga hama bersifat racun perut yang bisa menyebabkan serangga hama mati, sehingga daun sirsak dapat dimanfaatkan sebagai penanggulangan hama seperti belalang dan hama lain. Kandungan yang terdapat pada jeruk nipis, kenikir dan serai yaitu minyak atsiri dan silika yang berperan dapat menyebabkan dehidrasi pada tubuh serangga, sehingga menyebabkan perih dan panas pada tubuh serangga hama (Harinta 2013).

Terjadi perbedaan mortalitas antara perlakuan dosis tepung daun yang diujikan mungkin disebabkan karena perbedaan kombinasi antara jenis perlakuan dengan dosis. Dengan meningkatnya dosis maka mortalitas akan semakin meningkat. Berdasar hasil belum didapat dosis tepung yang efektif untuk menekan serangga hama $C$. analis, karena belum menimbulkan mortalitas $80 \%$. Sesuai dengan pernyataan Munford dan Norton (1984), bahwa suatu insektisida dianggap efektif apabila dapat menekan populasi serangga hama minimal $80 \%$ atau perkembangan populasi serangga hama menjadi lebih kecil dari $20 \%$.

\section{Jumlah telur yang diletakkan imago betina C. analis}

Berdasarkan hasil sidik ragam, bahwa jumlah telur yang di letakkan imago betina $C$. analis pada $5 \mathrm{hsp}$ menunjukkan semua perlakuan yang diujikan berbeda sangat nyata. Selanjutnya hasil analisis Uji Beda Nyata Jujur (BNJ) pada taraf ketidak percayaan 5\% menunjukkan bahwa jumlah telur yang diletakkan imago $C$. analis pada perlakuan $3 \mathrm{~g}$ berbeda nyata dengan dosis lainnya dan kontrol.

Pada pengamatan jumlah telur yang diletakkan terdapat berbagai macam perlakuan yang berbeda diantaranya tepung daun sirsak, serai, kenikir, jeruk nipis dan kluwih. Hasil terbaik pengaruh tepung daun terhadap jumlah telur yang diletakkan pada hari ke 5, 1 bulan, 2 bulan, dan 3 bulan adalah perlakuan sirsak dosis $3 \mathrm{~g}$ (B3). Jumlah telur pada hari ke 5 didapatkan sejumlah 139 butir, 1 bulan sejumlah 119,20 butir, 2 bulan sejumlah 91,20 butir, dan 3 bulan sejumlah 72,20 butir.

Hasil jumlah telur terbanyak yang diletakkan terdapat pada perlakuan tepung daun kluwih dosis $1 \mathrm{~g}$ (F1) mulai dari hari 5 hingga 3 bulan berturut turut. Jumlah telur hari ke 5 sejumlah 221,60 butir, 1
Tabel 3. Pengaruh tepung daun terhadap jumlah telur yang diletakkan imago betina $C$. analis pada 5 hari, 1 bulan, 2 bulan, dan 3 bulan setelah perlakuan.

\begin{tabular}{lllll}
\hline \multirow{2}{*}{ Perlakuan } & \multicolumn{4}{c}{ Mortalitas pada } \\
\cline { 2 - 5 } A hari & 1 bulan & 2 bulan & 3 bulan \\
\hline$B_{1}$ & $431,60 \mathrm{a}$ & $430,60 \mathrm{a}$ & $428,00 \mathrm{a}$ & $421,40 \mathrm{a}$ \\
$\mathrm{B}_{2}$ & $167,60 \mathrm{ghij}$ & $144,00 \mathrm{hi}$ & $125,80 \mathrm{fg}$ & $106,40 \mathrm{gh}$ \\
$\mathrm{B}_{3}$ & $139,00 \mathrm{l}$ & $119,20 \mathrm{j}$ & $91,20 \mathrm{~h}$ & $72,20 \mathrm{i}$ \\
$\mathrm{C}_{1}$ & $211,00 \mathrm{bc}$ & $191,60 \mathrm{c}$ & $171,20 \mathrm{~cd}$ & $158,20 \mathrm{bc}$ \\
$\mathrm{C}_{2}$ & $181,40 \mathrm{efg}$ & $169,60 \mathrm{def}$ & $150,20 \mathrm{de}$ & $141,40 \mathrm{cdef}$ \\
$\mathrm{C}_{3}$ & $164,60 \mathrm{hijk}$ & $154,20 \mathrm{fgh}$ & $137,40 \mathrm{efg}$ & $125,40 \mathrm{efg}$ \\
$\mathrm{D}_{1}$ & $194,40 \mathrm{de}$ & $185,00 \mathrm{~cd}$ & $170,60 \mathrm{~cd}$ & $152,80 \mathrm{cde}$ \\
$\mathrm{D}_{2}$ & $178,00 \mathrm{fgh}$ & $165,80 \mathrm{efg}$ & $155,20 \mathrm{cde}$ & $142,00 \mathrm{cdef}$ \\
$\mathrm{D}_{3}$ & $159,80 \mathrm{ijk}$ & $149,40 \mathrm{ghi}$ & $131,20 \mathrm{efg}$ & $118,20 \mathrm{fgh}$ \\
$\mathrm{E}_{1}$ & $172,20 \mathrm{ghi}$ & $162,00 \mathrm{efgh}$ & $144,60 \mathrm{ef}$ & $128,80 \mathrm{defg}$ \\
$\mathrm{E}_{2}$ & $166,20 \mathrm{ghij}$ & $156,60 \mathrm{fgh}$ & $138,00 \mathrm{efg}$ & $110,40 \mathrm{gh}$ \\
$\mathrm{E}_{3}$ & $156,00 \mathrm{jk}$ & $148,60 \mathrm{ghi}$ & $131,60 \mathrm{efg}$ & $107,40 \mathrm{gh}$ \\
$\mathrm{F}_{1}$ & $221,60 \mathrm{bc}$ & $216,20 \mathrm{~b}$ & $200,60 \mathrm{~b}$ & $183,40 \mathrm{~b}$ \\
$\mathrm{~F}_{2}$ & $202,80 \mathrm{~cd}$ & $192,60 \mathrm{c}$ & $175,60 \mathrm{c}$ & $156,80 \mathrm{bcd}$ \\
$\mathrm{F}_{3}$ & $191,40 \mathrm{def}$ & $176,80 \mathrm{cde}$ & $172,00 \mathrm{~cd}$ & $159,20 \mathrm{bc}$ \\
\hline
\end{tabular}

Keterangan: Angka-angka yang diikuti huruf yang sama pada kolom yang sama tidak berbeda nyata pada taraf $5 \%$ berdasar uji BNJ (data ditransformasi dengan akar kuadrat +1 sebelum dianalisis).

bulan sejumlah 216,20 butir, 2 bulan sejumlah 200,60 butir, dan 3 bulan sejumlah 183,40 butir (Tabel 3).

Jumlah telur yang diletakkan dapat diketahui bahwa perlakuan kontrol lebih tinggi dibandingkan dengan perlakuan tepung daun. Hal ini dikarenakan pemberian dosis tepung daun efektif memberikan gangguan terhadap serangga hama $C$. analis untuk peletakan telur, karena tepung menempel pada selasela biji kedelai sehingga mengotori permukaan biji kedelai, diduga dapat menyulitkan imago betina $C$. analis untuk menentukan tempat yang cocok sebagai wadah bertelur.

Seperti pernyataan Kardiman (2001), bahwa pestisida sirsak tidak membunuh hama secara cepat, namun berpengaruh terhadap sistem reproduksi serangga hama, ganti kulit, penghambat untuk menjadi serangga dewasa, sebagai pemandul, mengganggu dan menghambat proses perkawinan serangga, menghambat peletakan dan menurunkan daya tetas telur.

Menurut Rahayu et al. (2012), minyak atsiri yang terkandung dalam daun kenikir, daun serai, dan daun jeruk nipis dapat menimbulkan bau serta aroma yang tidak disukai serangga. Semakin meningkatnya dosis yang diberikan akan mengakibatkan menurunnya jumlah telur yang diletakkan. Hal ini karena semakin meningkatnya dosis akan mengakibatkan mortalitas yang semakin tinggi, sehingga jumlah telur yang diletakkan semakin berkurang. 


\section{Jumlah Telur Yang Menetas Menjadi Imago C. analis}

Berdasarkan hasil sidik ragam, semua perlakuan dengan kombinasi antara jenis tepung dengan dosis yang diujikan pengaruhnya terhadap jumlah telur yang menetas menjadi imago $C$. analis berbeda sangat nyata. Selanjutnya berdasarkan hasil analisis Uji Beda Nyata Jujur pada taraf ketidak percayaan $5 \%$, menunjukkan bahwa jumlah telur yang menetas menjadi imago $C$. analis pada perlakuan dosis $3 \mathrm{~g}$ berbeda nyata dengan dosis lain atau kontrol (Tabel 4). Imago muncul pada setiap perlakuan dilakukan pengamatan pada 1 bulan dan 2 bulan. Hasil terbaik pada pengamatan 1 bulan adalah perlakuan tepung daun sirsak dosis $3 \mathrm{~g}$ (B3) sejumlah 132,20 imago muncul, sedangkan pada pengamatan 2 bulan hasil terbaik adalah perlakuan tepung daun sirsak dosis 3 g (B3) sejumlah 79 imago muncul (Tabel 4).

Hasil pengamatan menunjukkan bahwa rata-rata jumlah telur yang menetas, kontrol lebih tinggi dibanding perlakuan lain. Hal ini di sebabkan karena perlakuan kombinasi antara jenis tepung dengan dosis dapat mengganggu perilaku dan proses pembuahan telur. Bisa dilihat bahwa semakin meningkatnya dosis yang diperlakukan, maka akan menekan pula persentase telur yang menetas menjadi imago. Sesuai dengan pernyataan Kardinan (2001), bahwa insektisida sirsak tidak dapat membunuh hama dengan cepat, tetapi berpengaruh mengurangi reproduksi, proses pergantian kulit, menghambat menjadi serangga dewasa, pemandul, menghambat proses perkawinan, peletakan telur dan daya tetas telur. Menurut Rahayu et al. (2012), minyak atsiri yg terkandung dalam daun serai, kenikir, dan jeruk nipis dapat mengganggu serangga hama dari bau

Tabel 4. Pengaruh tepung daun terhadap jumlah telur $C$. analis yang menetas menjadi imago F1 dan F2 (1 dan 2 bulan)

\begin{tabular}{llll}
\hline \multirow{2}{*}{ Perlakuan } & \multicolumn{3}{c}{$\begin{array}{c}\text { Imago muncul (ekor) pada setiap } \\
\text { perlakuan dan pada pengamatan }\end{array}$} \\
\cline { 2 - 4 } & F1 (1 bulan) & F2 $(2 \mathrm{bulan})$ \\
\hline A & 429,80 & $\mathrm{a}$ & $411,40 \mathrm{a}$ \\
B1 & 162,60 & $\mathrm{defg}$ & $117,00 \mathrm{fg}$ \\
B2 & 146,60 & $\mathrm{fgh}$ & $98,60 \mathrm{gh}$ \\
B3 & 132,20 & $\mathrm{~h}$ & $79,00 \mathrm{~h}$ \\
C1 & 202,20 & $\mathrm{bc}$ & $167,00 \mathrm{~cd}$ \\
C2 & 180,40 & $\mathrm{~cd}$ & $147,60 \mathrm{cdef}$ \\
C3 & 156,00 & efgh & $136,60 \mathrm{def}$ \\
D1 & 186,00 & cd & $160,00 \mathrm{de}$ \\
D2 & 174,40 & de & $144,20 \mathrm{cdef}$ \\
D3 & 162,60 & defg & $124,80 \mathrm{fg}$ \\
E1 & 166,80 & def & $135,20 \mathrm{def}$ \\
E2 & 166,60 & def & $129,00 \mathrm{efg}$ \\
E3 & 139,00 & gh & $126,00 \mathrm{fg}$ \\
F1 & 212,80 & $\mathrm{~b}$ & $201,80 \mathrm{~b}$ \\
F2 & 198,40 & bc & $176,80 \mathrm{bc}$ \\
F3 & 178,60 & cde & $161,20 \mathrm{de}$ \\
\hline
\end{tabular}

Keterangan: Angka-angka yang diikuti huruf yang sama pada kolom yang sama tidak berbeda nyata pada taraf $5 \%$ berdasar uji $\mathrm{BNJ}$ yang menyengat, sehingga proses peletakan telur akan sulit di tentukan oleh serangga betina $C$. analis.

\section{Kerusakan Biji Dan Penyusutan Bobot Biji Kedelai}

Hasil pengamatan menunjukan perlakuan dosis tepung daun sirsak $3 \mathrm{~g} / 500 \mathrm{~g}$ biji kedelai merupakan perlakuan dengan hasil yang paling baik. Sesuai dengan pernyataan Wahyuni (2004), bahwa persentase kerusakan biji kedelai akibat serangga $C$. analis semakin rendah dengan semakin rendahnya tingkat populasi. Pengaruh serangga $C$. analis terhadap kerusakan biji didapatkan hasil terbaik pada perlakuan tepung daun sirsak dosis $3 \mathrm{~g}$ (B3) sejumlah 67,4 butir kerusakan, sedangkan hasil susut bobot biji terbaik didapat pada perlakuan tepung daun sirsak dosis $3 \mathrm{~g}$ (B3) sejumlah 17,94 g (Tabel 5).

Hasil pengamatan menunjukan bahwa rendahnya kerusakan biji akan memperkecil penyusutan bobot biji kedelai. Hal ini disebabkan dengan sedikitnya biji yang rusak, maka susut bobot biji kedelai yang ditimbulkan akan semakin rendah. Hal ini sesuai dengan pernyataan Soekarna (1982), bahwa besarnya kerusakan dan penyusutan bobot biji di tempat penyimpanan tergantung dari tinggi rendahnya kepadatan populasi serangga hama. Populasi C. analis yang semakin padat, kerusakan dan penyusutan bobot biji akan semakin meningkat.

\section{Analisis Probit $\mathbf{L T}_{50}$}

Penentuan $\mathrm{LT}_{50}$ serangga uji diperlukan untuk mengetahui berapa kisaran waktu suatu perlakuan tepung daun dapat mematikan populasi serangga

Tabel 5. Pengaruh tepung daun terhadap kerusakan biji dan susut bobot biji kedelai.

\begin{tabular}{lllll}
\hline Perlakuan & $\begin{array}{l}\text { Kerusakan biji } \\
\text { (butir) }\end{array}$ & \multicolumn{2}{l}{$\begin{array}{l}\text { Susut bobot biji } \\
\text { (gr) }\end{array}$} \\
\hline A & 438,60 & a & 198,67 & a \\
B1 & 85,00 & ef & 35,11 & fg \\
B2 & 79,20 & f & 25,96 & gh \\
B3 & 67,40 & f & 17,94 & h \\
C1 & 110,40 & cd & 72,18 & cd \\
C2 & 110,20 & cd & 64,45 & de \\
C3 & 88,40 & def & 55,10 & e \\
D1 & 122,20 & c & 73,72 & cd \\
D2 & 87,60 & def & 64,38 & de \\
D3 & 72,00 & f & 54,21 & e \\
E1 & 107,80 & cde & 64,65 & de \\
E2 & 85,80 & ef & 48,52 & ef \\
E3 & 83,40 & f & 54,75 & e \\
F1 & 174,20 & b & 102,26 & b \\
F2 & 155,80 & b & 92,77 & b \\
F3 & 128,80 & c & 86,39 & bc \\
\hline
\end{tabular}

Keterangan: Angka-angka yang diikuti huruf yang sama pada kolom yang sama tidak berbeda nyata pada taraf $5 \%$ berdasar uji BNJ. 
Tabel 6. Analisis probit penetapan LT50 C. analis pada konsentrasi 1, 2, $3 \mathrm{~g}$

\begin{tabular}{|c|c|c|c|c|}
\hline Perlakuan & Dosis & $\mathrm{LT}_{50}$ (hari) & Pers. Regresi & $\mathrm{R}^{2}$ \\
\hline & 1 & 15,745 & $y=0,703+3,589 x$ & 0,8311 \\
\hline \multirow[t]{3}{*}{ Sirsak } & 2 & 12,432 & $\mathrm{y}=0,274+4,317 \mathrm{x}$ & 0,9309 \\
\hline & 3 & 9,0747 & $y=1,367+3,793 x$ & 0,6478 \\
\hline & 1 & 27,538 & $y=-1,025+4,184 x$ & 0,8407 \\
\hline \multirow[t]{3}{*}{ Serai } & 2 & 24,002 & $y=-0,263+3,813 x$ & 0,8485 \\
\hline & 3 & 19,498 & $y=-0,597+4,339 x$ & 0,2504 \\
\hline & 1 & 32,641 & $y=0,818+3,795 x$ & 0,8522 \\
\hline \multirow[t]{3}{*}{ Kenikir } & 2 & 29,145 & $\mathrm{y}=0,183+3,289 \mathrm{x}$ & 0,7032 \\
\hline & 3 & 23,291 & $y=-0,372+3,929 x$ & 0,3495 \\
\hline & 1 & 17,484 & $y=0,305+3,778 x$ & 0,7973 \\
\hline \multirow[t]{3}{*}{ Jeruk Nipis } & 2 & 14,069 & $y=-1,282+5,471 x$ & 0,85 \\
\hline & 3 & 13,046 & $y=0,609+3,937 x$ & 0,9007 \\
\hline & 1 & 25,486 & $y=-0,863+4,169 x$ & 0,8021 \\
\hline \multirow[t]{2}{*}{ Kluwih } & 2 & 23,583 & $y=-1,137+4,471 x$ & 0,7728 \\
\hline & 3 & 19,822 & $y=-0,342+4,118 x$ & 0,8256 \\
\hline
\end{tabular}

Keterangan: Angka-angka yang diikuti huruf yang sama pada kolom yang sama tidak berbeda nyata pada taraf 5\% berdasar uji BNJ.

hama hingga mencapai 50\%. Berdasarkan data mortalitas, nilai analisis probit $\mathrm{LT}_{50}$ pada setiap perlakuan dengan kombinasi dosis yang diberikan menunjukan hasil yang berbeda dari setiap tepung daun. Diketahui bahwa perlakuan sirsak menunjukan pengaruh paling cepat yaitu pada dosis terkecil 1 g didapatkan 15,745 hari untuk mendapatkan mortalitas populasi $C$. analis hingga 50\%. Perbedaan nilai $\mathrm{LT}_{50}$ yang didapat, diduga karena perbedaan suatu bahan toksik perlakuan. Perlakuan sirsak dengan kandungan asetogenin yaitu racun perut, diduga senyawa ini berpengaruh cepat terhadap serangga uji yang diberikan. Analisis probit menunjukan bahwa semakin besar dosis yang diberikan nilai $\mathrm{LT}_{50}$ yang dihasilkan akan semakin baik, bahwa sirsak 3 g menunjukan pada hari 9,074 dapat menekan $50 \%$ populasi C. analis (Tabel 6). Semakin besar dosis perlakuan yang diberikan, berpengaruh terhadap serangga uji akan semakin cepat.

Nilai $\mathrm{LT}_{50}$ pada daun sirsak tampak lebih tinggi daripada perlakuan lain. Menurut Novizan (2002) bahwa daun dan biji sirsak menggandung senyawa aktif annonain dan asetogenin yang berfungsi sebagai insektisida, repelen, dan antifeedant. Secara umum, bahan tersebut dapat berperan sebagai insektisida nabati. Daun sirsak mengandung senyawa asetogenin, bagi serangga hama bersifat racun perut yang bisa mengakibatkan serangga hama mati, sehingga daun sirsak dapat dimanfaatkan untuk menanggulangi hama seperti belalang dan hama lain (Kardiman 2005). Pestisida sirsak tidak membunuh hama secara cepat, tetapi berpengaruh mengurangi reproduksi, proses ganti kulit, hambatan menjadi serangga dewas, sebagai pemandul, mengganggu dan menghambat proses perkawinan serangga, menghambat peletakkan dan penurunan daya tetes telur (Kardinan 2001).

Berdasarkan hasil penelitian yang telah dilakukan disimpulkan bahwa perlakuan paling efektif yang dapat meningkatkan mortalitas $C$. analis adalah perlakuan sirsak dengan pemberian dosis $2 \mathrm{~g}$ (3,57 ekor). Penambahan dosis setiap perlakuan dapat meingkatkan presentase mortalias C. analis. Pada jumlah peletakkan telur, perlakuan sirsak dengan dosis $2 \mathrm{~g}$ (91,20 butir) paling baik menekan peletakkan telur oleh $C$. analis. Pada jumlah telur menetas, perlakuan sirsak dosis $2 \mathrm{~g}$ (98,60 ekor) paling baik dalam menekan jumlah tetas telur C. analis dibandingkan perlakuan lain.

Pada kerusakan biji, perlakuan sirsak dengan pemberian dosis $1 \mathrm{~g}$ (85 butir) paling efektif dalam menekan kerusakan biji yang ditimbulkan oleh $C$. analis lebih rendah dibandingkan perlakuan kontrol (438,60 butir).

Pada susut bobot biji, perlakuan sirsak dosis $2 \mathrm{~g}$ (25,96 g) paling efektif menekan susut bobot biji yang ditimbulkan $C$. analis lebih rendah dibanding perlakuan kontrol $(198,67$ g). Selain itu, analisis Probit dapat menentukan kapasitas daya racun suatu insektisida, bahwa semakin besar dosis yang diberikan, daya racun akan semakin cepat berpengaruh terhadap kematian $C$. analis.

\section{Pernyataan tidak ada konfik kepentingan}

Semua penulis artikel ini menyatakaan bahwa tidak ada konflik kepentingan terkait penelitian dan hasil penelitian ini. 


\section{DAFTAR PUSTAKA}

Badan Pusat Statistik. 2017. Produksi Kedelai 2016-2017. https://bps.go.id/.

Harinta YW. 2013. Efektifitas tepung daun sirsak (Annona muricata) untuk mengendalikan kumbang bubuk kedelai $(C$. analis F.) pada biji kedelai (Glycine max L.). Agrovigor 6 (2): 121-128. DOI: 10.21107/agrovigor.v6i2.1487.

Kardiman A. 2005. Pestisida Nabati, Kemampuan dan Aplikasi. Jakarta (ID): Penebar Swadaya.

Kardiman A. 2001. Pestisida Nabati: Ramuan dan Aplikasi. Jakarta (ID): Penebar Swadaya.

Munford dan Norton. 1984. Economic of decition making innpest management. Annual Review of Entomology 29: 157-174. DOI: 10.1146/annurev.en.29.010184.001105.
Novizan. 2002. Membuat dan Memanfaatkan Pestisida Ramah Lingkungan. Tanggerang (ID): Agromedia Pustaka.

Rahayu M, Terry P, Ramlia S. 2012. Uji konsentrasi cairan perasan daun kenikir (Tagetes patula Juss) terhadap mortalitas ulat penggulung daun (Lamprosema indica) pada tanaman ubi jalar. Agroteknos 2 (1): 36-40.

Soekarna. 1982. Serangga-Serangga Gudang dan Pengendaliaannya. Bogor (ID): Direktorat Perlindungan Tanaman Pangan.

Suranto A. 2011. Dahsyatnya Sirsak Tumpas Penyakit. Jakarta (ID): Pustaka Bunda.

Wahyuni M. 2004. Pestisida Nabati untuk Pengendalian Hama Tanaman Pertanian yang Ramah Lingkungan. Banyumas (ID): Balai Penyuluhan Pertanian Kaliori. 